\title{
Analisis Pendekatan Saintifik sebagai Indikator Berpikir Ilmiah dalam Pembelajaran Sejarah
}

\author{
Ofianto, Tri Zahra Ningsih
}

ofianto.anto@yahoo.com

Universitas Negeri Padang, SMP Negeri 46 Kerinci

\begin{abstract}
.
Scientific thinking is an important skill in learning history. Scientific thinking skills in history learning include historical thinking skills and historical reasoning skills that require the use of scientific steps in the reconstruction of historical narratives. So that to develop these skills, comprehensive and diagnostic methods, and indicators are needed so that students' scientific thinking potential can be achieved. However, in the 2013 curriculum, there are no specific indicators that can be used as a benchmark to improve scientific thinking skills in history learning. The 2013 curriculum generalizes scientific thinking indicators for all subjects through a scientific approach. This will certainly raise the question of whether the scientific approach can increase the potential of students' scientific thinking in learning history, considering that each subject has specific learning objectives including history learning. Based on this, this study aims to analyze the extent to which the scientific approach in the 2013 curriculum can be an appropriate indicator in improving scientific thinking skills for learning history. This research is quantitative descriptive research with a survey method. The research subjects consisted of 60 high school students. Data were collected through observation, interviews, and written tests in the form of descriptions. The research data were analyzed using the Partial Credit Model (PCM) with the help of the Quest program. The results showed that the scientific approach was only able to increase the potential of students' scientific thinking in learning history by $35.66 \%$ with a very low category. This means that the scientific approach has not been able to become a good indicator of scientific thinking, especially for history learning.
\end{abstract}

Keywords: Scientific Approach, Scientific Thinking, History Learning

\begin{abstract}
Abstrak
Berpikir ilmiah merupakan keterampilan penting dalam pembelajaran sejarah. Keterampilan berpikir ilmiah dalam pembelajaran sejarah mencakup keterampilan berpikir historis dan keterampilan penalaran sejarah yang menuntut penggunaan langkah-langkah ilmiah dalam rekonstruksi narasi sejarah. Sehingga untuk mengembangkan keterampilan ini diperlukan caracara dan indikator yang bersifat komprehensif dan diagnostik agar potensi berpikir ilmiah siswa benar-benar dapat tercapai. Namun, dalam kurikulum 2013 belum ada indikator khusus yang dapat menjadi kriteria untuk meningkatkan keterampilan berpikir ilmiah dalam pembelajaran sejarah. Kurikulum 2013 menggeneralisasi indikator berpikir ilmiah untuk semua mata pelajaran melalui pendekatan saintifik. Hal ini tentunya akan menimbulkan pertanyaan apakah pendekatan saintifik benar-benar dapat meningkatkan potensi berpikir ilmiah siswa dalam pembelajaran sejarah, mengingat setiap mata pelajaran memiliki tujuan pembelajaran yang spesifik termasuk pembelajaran sejarah. Berdasarkan hal tersebut, penelitian ini bertujuan untuk menganalisis sejauh mana pendekatan saintifik dalam kurikulum 2013 mampu menjadi indikator yang tepat dalam meningkatkan keterampilan berpikir ilmiah untuk pembelajaran sejarah. Penelitian ini
\end{abstract}


merupakan penelitian deskriptif kuantitatif dengan metode survey. Subjek penelitian terdiri dari 60 siswa Sekolah Menengah Atas. Pengumpulan data dilakukan melalui kegiatan observasi, wawancara, dan tes tertulis dalam bentuk uraian. Data hasil penelitian dianalisis dengan menggunakan Partial Credit Model (PCM) melalui bantuan program Quest versi 2.0. Hasil penelitian menunjukkan bahwa pendekatan saintifik hanya mampu meningkatkan potensi berpikir ilmiah siswa dalam pembelajaran sejarah sebesar 35,66\% dengan kategori sangat rendah. Hal ini berarti bahwa pendekatan saintifik belum mampu menjadi indikator berpikir ilmiah yang baik khususnya untuk pembelajaran sejarah.

Kata Kunci: Pendekatan Saintifik, Berpikir Ilmiah, Pembelajaran Sejarah

(C) (D) (2) This work is licensed under the Creative Commons Attribution-ShareAlike 4.0
International License

\section{Pendahuluan}

Berpikir ilmiah telah menjadi topik penelitian intensif dan spekulatif selama hampir 400 tahun (Bacon, 1854; Galilei, 1914; Klahr, 2000; Tweney et al., 1981). Berpikir ilmiah merupakan bagian dari berpikir tingkat tinggi (HOTS) yang dapat meningkatkan kemampuan berpikir kritis, analitis, sikap terbuka, kejujuran, tanggung jawab, dan kerjasama siswa dalam proses pembelajaran (Abdullah, 2014; Napitupulu et al., 2019; Pitafi \& Farooq, 2012). Dalam pembelajaran sejarah, keterampilan berpikir ilmiah mencakup keterampilan berpikir historis (historical thinking skill) dan keterampilan penalaran sejarah (historical reasoning skill) karena menuntut langkah-langkah ilmiah dalam kegiatan rekonstruksi narasi sejarah (van Boxtel et al., 2021). Berpikir historis merupakan suatu proses kognitif dimana siswa menggunakan pengetahuan prosedural dalam penyelidikan untuk menginterpretasi masa lalu(Duquette, 2015; Peter Seixas \& Peck, 2004). Berpikir historis bukan hanya tentang pengetahuan konseptual semata, akan tetapi tentang penyatuan pengetahuan konseptual dan metode penelitian sejarah, sehingga pencapaian kompetensi yang diharapkan tidak hanya sekedar menambah pengetahuan tentang apa yang dicari, tetapi juga pengembangan keterampilan yang lebih kompleks tentang bagaimana mencari pengetahuan tersebut (Martínez-Hita et al., 2021; P. Seixas, 2013). Sedangkan penalaran sejarah merupakan subkategori dari konsep berpikir tingkat tinggi yang terdiri dari aktivitas mental seperti menganalisis, mensintesis, membuat hipotesis, menggeneralisasi, dan interpretasi (van Boxtel et al., 2021). Penalaran sejarah dicirikan dengan penggunaan konsep metodologis historis dan substantif dalam rekonstruksi narasi sejarah (Van Drie \& Van Boxtel, 2008). Berdasarkan teori di atas, disimpulkan bahwa dua konsep keterampilan berpikir ilmiah dalam pembelajaran sejarah baik keterampilan berpikir historis maupun keterampilan penalaran sejarah menuntut proses kognisi tingkat tinggi (Higher Order Thinking Skills) melalui metode-metode ilmiah. Sehingga dalam pengembangan keterampilan berpikir ilmiah khususnya dalam pembelajaran sejarah memerlukan cara-cara dan indikator yang bersifat komprehensif dan diagnostik agar potensi berpikir ilmiah siswa benar-benar dapat tercapai. Beberapa studi 
Ofianto, Tri Zahra Ningsih

Analisis Pendekatan Saintifik sebagai Indikator Berpikir Ilmiah dalam

Pembelajaran Sejarah

menyebutkan bahwa dalam mengembangkan keterampilan berpikir ilmiah dalam pembelajaran sejarah dibutuhkan keterampilan berpikir historis, keterampilan penalaran sejarah, keterampilan literasi sejarah, dan kesadaran sejarah (historical consciousness) (Efstathiou et al., 2018; Innes, 2020; Peter Seixas, 2017).

Keterampilan berpikir historis, keterampilan penalaran sejarah, keterampilan literasi sejarah, dan kesadaran sejarah memiliki keterkaitan antara satu dan lainnya untuk membangun keterampilan berpikir ilmiah siswa dalam pembelajaran sejarah (Lee, 2007; Peter Seixas, 2006; Van Boxtel \& van Drie, 2018). Namun, berdasarkan pengamatan dan hasil wawancara peneliti dengan beberapa guru sejarah, diketahui bahwa keempat keterampilan belum pernah dijadikan sebagai indikator berpikir ilmiah dalam pembelajaran sejarah. Hal ini disebabkan karena Kurikulum 2013 menempatkan pendekatan saintifik yang dikenal dengan 5M (mengamati, menanya, mengeksplorasi, menganalisis, dan menggeneralisasi) sebagai indikator umum untuk mengembangkan keterampilan berpikir ilmiah bagi semua mata pelajaran. Padahal setiap mata pelajaran mempunyai spesifikasi tujuan masing-masing yang sejatinya memerlukan cara-cara khusus pula dalam pencapaiannya.

Berdasarkan permasalahan tersebut, maka perlu dilakukan analisis sejauh mana konsep pendekatan saintifik 5M dapat dijadikan sebagai indikator berpikir ilmiah dalam pembelajaran sejarah. Analisis ini penting dilakukan untuk melihat kontribusi setiap indikator pendekatan ilmiah 5M dalam meningkatkan keterampilan berpikir ilmiah siswa dalam pembelajaran sejarah.

\section{Metode Penelitian}

Penelitian ini merupakan penelitian deskriptif kuantitatif dengan metode survey yang bertujuan untuk memperoleh informasi tentang gambaran kemampuan berpikir ilmiah siswa serta menganalisis apakah pendekatan saintifik 5M dapat dijadikan sebagai indikator untuk mengembangakan keterampilan berpikir ilmiah dalam pembelajaran sejarah di sekolah. Subjek penelitian adalah 60 siswa kelas X Sekolah Menengah Atas. Pemilihan subjek penelitian dilakukan dengan pertimbangan bahwa kelas $X$ merupakan tingkat paling dasar untuk jenjang Sekolah Menengah Atas (SMA), sehingga analisis keterampilan berpikir ilmiah akan lebih baik jika dilakukan sedari awal. Pengumpulan data dilakukan melalui observasi, wawancara, dan tes tertulis dalam bentuk uraian. Observasi dan wawancara dilakukan terhadap guru-guru mata pelajaran sejarah yang bertujuan untuk mengetahui proses pembelajaran di sekolah. Observasi dan wawancara juga dilakukan untuk mendapatkan gambaran terhadap indikator berpikir ilmiah yang berlaku di sekolah. Tes digunakan untuk mengukur tingkat keterampilan berpikir ilmiah siswa. Tes terdiri dari 5 butir soal yang disesuaikan dengan karakteristik kemampuan berpikir ilmiah. Penskoran setiap butir soal disesuaikan dengan kriteria kategori jawaban yang ditetapkan. Rubrik penskoran kemampuan berpikir ilmiah mengikuti kriteria Partial 
Credit Model (PCM) data Politomus dengan menggunakan tiga kategori berdasarkan pencapaian indikator jawaban (Wright \& Masters, 1982). Interpretasi respon peserta tes untuk setiap kategori mengacu pada model penskoran yang dikemukakan oleh Andrich (1978) yaitu dengan alternative skala peringkat. Rubrik penskoran kemampuan berpikir ilmiah disajikan pada tabel 1.

\begin{tabular}{|c|c|c|c|}
\hline No & Aspek Berpikir Ilmiah & Indikator Pencapaian & Kriteria Penskoran \\
\hline 1. & Mengamati/Memahami & $\begin{array}{l}\text { 1. Mampu merumuskan tujuan } \\
\text { dengan jelas } \\
\text { 2. Mampu mengidentifikasi hasil } \\
\text { pengamatan atau fenomena }\end{array}$ & \multirow{6}{*}{$\begin{array}{c}\text { Skor } 0 \text { kategori } 1 \text { : jika } \\
\text { jawaban salah }\end{array}$} \\
\hline \multirow[t]{2}{*}{2.} & $\begin{array}{l}\text { Menanya/ } \\
\text { merumuskan } \\
\text { pertanyaan }\end{array}$ & $\begin{array}{l}\text { 1. Mampu } \\
\text { masalah dari hasil pengamatan/ } \\
\text { pemahaman }\end{array}$ & \\
\hline & & Mampu membuat hipotesis & \\
\hline 3. & $\begin{array}{l}\text { Mencari sumber } \\
\text { data/mengumpulkan } \\
\text { informasi }\end{array}$ & $\begin{array}{l}\text { 1. Mampu mengumpulkan } \\
\text { informasi dari berbagai bahan/literatur } \\
\text { 2. Mampu mengidentifikasi } \\
\text { informasi dari berbagai bahan/literatur } \\
\text { yang relevan untuk menjawab rumusan } \\
\text { masalah }\end{array}$ & \\
\hline 4. & Melakukan penalaran & $\begin{array}{l}\text { 1. Mampu menalar dan } \\
\text { menganalisis hasil identifikasi dari } \\
\text { berbagai bahan/literatur yang relevan } \\
2 . \quad \text { Mampu membuat kesimpulan } \\
\text { dan mencocokkan kesimpulan dengan } \\
\text { hipotesis }\end{array}$ & \\
\hline 5. & $\begin{array}{l}\text { Mengaplikasikan/men } \\
\text { gkomunikasikan }\end{array}$ & $\begin{array}{l}\text { 1. Mampu menyajikan hasil kerja } \\
\text { dalam bentuk narasi tertulis } \\
\text { 2. Mampu } \\
\text { mempertanggungjawabkan hipotesis }\end{array}$ & \\
\hline
\end{tabular}

Tabel 1. Rubrik penskoran kemampuan berpikir ilmiah

Data hasil penelitian dianalisis dengan menggunakan Partial Credit Model (PCM) dengan komputasi data menggunakan bantuan program Quest versi 2.0. Penetapan fit item dan testi secara keseluruhan dengan model dalam program Quest (Adams \& Khoo, 
Ofianto, Tri Zahra Ningsih

Analisis Pendekatan Saintifik sebagai Indikator Berpikir Ilmiah dalam

Pembelajaran Sejarah

1996) didasarkan pada besarnya nilai-nilai INFIT Mean of Square (INFIT MNSQ) beserta simpangan bakunya atau nilai rata-rata INFIT Mean of INFIT t. Suatu item atau testi dinyatakan fit dengan model dengan batas kisaran INFIT MNSQ dari 0,77 sampai 1,30 (Adams \& Khoo, 1996). Penetapan reliabilitas instrumen didasarkan pada nilai Internal Consistency. Tingkat kesukaran butir soal mempunyai rentang \pm 2 (antara -2 hingga +2 ), dengan interpretasi nilai -2 menunjukkan butir soal sangat mudah dan +2 menunjukkan butir soal sangat sulit (Hambleton \& Swaminathan, 1985).

\section{Hasil dan Pembahasan}

\section{Validitas dan Reliabilitas instrument}

Validitas item diuji melalui Partial Credit Model (PCM) dengan komputasi data menggunakan bantuan program Quest. Penetapan valid atau tidaknya sebuah item mengikuti kriteria yang ditetapkan oleh Adam \& Khoo (1996) yaitu jika nilai suatu item terletak pada garis INFIT MNSQ antara skor 0,77 hingga 1.30 maka item tersebut dinyatakan valid untuk digunakan sebagai instrumen mengukur keterampilan berpikir ilmiah siswa. Data uji validitas item berasal dari hasil tes keterampilan berpikir ilmiah yang dilakukan terhadap 60 orang siswa. Adapun hasil validitas item yang dianalisis dengan menggunakan program quest versi 2.0 disajikan pada figure 1.

kemampuan berpikir ilmiah

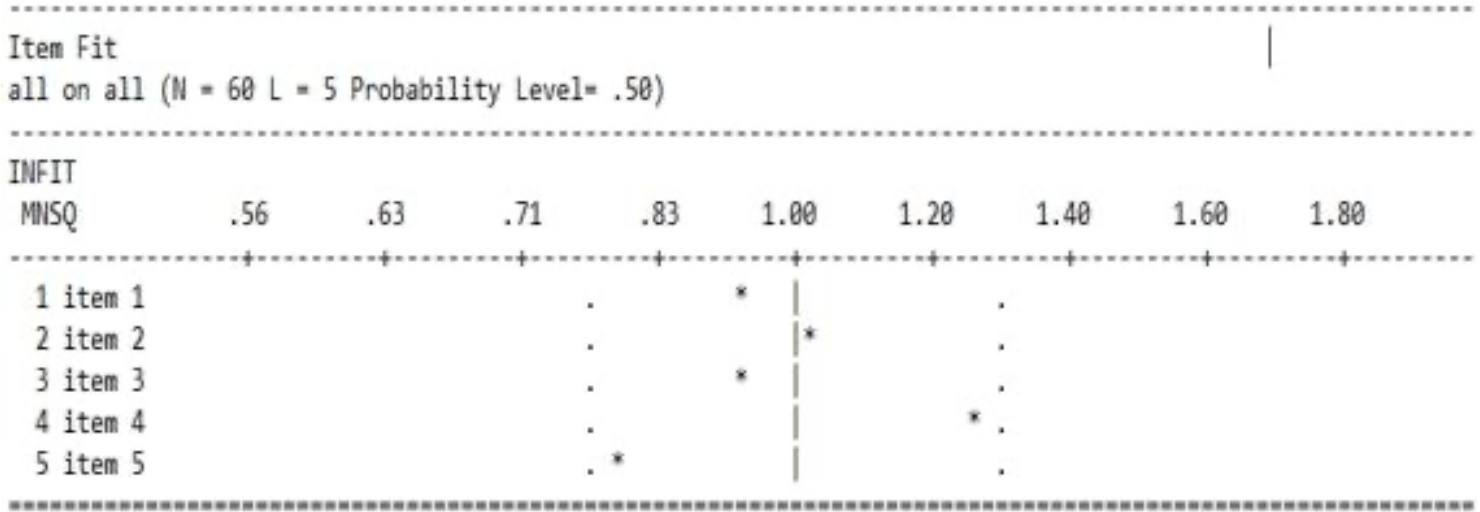

Figure 1. validitas item butir soal kemampuan berpikir ilmiah

Berdasarkan Figure 1 dapat diketahui bahwa seluruh item butir soal untuk mengukur kemampuan berpikir ilmiah adalah valid karena nilai fit Item berada di antara 0.77 dan 1.30. Nilai validitas untuk setiap item disajikan pada Tabel 3. 
DIAKRONIKA 21 (1) 2021

ISSN: 1411-1764 (Print) | 2620-9446 (Online)

\begin{tabular}{|llcc|}
\hline No & \multicolumn{1}{|c}{ Aspek Berpikir Ilmiah } & $\begin{array}{c}\text { Nomor butir } \\
\text { soal }\end{array}$ & $\begin{array}{c}\text { Nilai Validitas } \\
\text { (INFIT Mean of } \\
\text { Square) }\end{array}$ \\
\hline 1. & Mengamati/Memahami & 1 & 0.93 \\
\hline 2. & Menanya/ merumuskan pertanyaan & 2 & 1.01 \\
\hline 3. & $\begin{array}{l}\text { Mencari sumber data/mengumpulkan } \\
\text { informasi }\end{array}$ & 3 & 0.93 \\
\hline 4. & Melakukan penalaran & 4 & 1.27 \\
\hline 5. & Mengaplikasikan/mengkomunikasikan & 5 & 0.79 \\
\hline
\end{tabular}

Tabel 2. Nilai validitas tes uraian berpikir ilmiah

Berdasarkan tabel 3 di atas, dengan mengikuti kriteria validitas item yang ditetapkan oleh (Adams \& Khoo, 1996), maka skor validitas item yang berada diantara 0.77 hingga 1.30 dinyatakan valid untuk digunakan sebagai instrumen dalam mengukur keterampilan berpikir ilmiah siswa dalam pembelajaran sejarah.

Selanjutnya penentuan reliabilitas instrumen didasarkan pada nilai Internal Consistency. Adapun kriteria nilai reliabilitas instrumen dalam penelitian ini mengikuti kriteria yang ditetapkan oleh Sundayana (2016) sebagai berikut :

\begin{tabular}{|ll|}
\hline Koefisien Reliability (r) & Kategori \\
\hline $0,00 \leq \mathrm{r} \leq 0,20$ & Tidak Reliabel \\
\hline $0,20 \leq \mathrm{r} \leq 0,40$ & Kurang Reliabel \\
\hline $0,40 \leq \mathrm{r} \leq 0,60$ & Cukup Reliabel \\
\hline $0,60 \leq \mathrm{r} \leq 0,80$ & Reliabel \\
\hline $0,80 \leq \mathrm{r} \leq 1.00$ & Sangat Reliabel \\
\hline
\end{tabular}

Tabel 3. Kriteria tingkat reliabilitas instrument

Nilai reliabilitas instrumen pengukuran kemampuan berpikir ilmiah dapat dilihat pada Figure 2.

Item Analysis Results for Observed Responses 


\section{Ofianto, Tri Zahra Ningsih}

\section{Analisis Pendekatan Saintifik sebagai Indikator Berpikir Ilmiah dalam}

Pembelajaran Sejarah

$\mid \begin{array}{lc}\text { all on all }(\mathrm{N}=60 \mathrm{~L}=5 \text { Probability Level= .50) } \\ \text { Mean test score } \quad 9.97 \\ \text { Standard deviation } & 3.92 \\ \text { Internal Consistency } & .66\end{array}$

Figure 2. Reliabilitas instrumen tes kemampuan berpikir ilmiah

Berdasarkan Figure 2 diketahui bahwa nilai reliabilitas yang ditunjukkan oleh skor Internal Consistency adalah sebesar 0.66, maka berdasarkan kriteria nilai reliabilitas yang telah ditetapkan dapat disimpulkan bahwa instrumen tes uraian yang digunakan untuk mengukur kemampuan berpikir ilmiah adalah reliabel.

2. Tingkat Kesukaran Butir Soal

Penetapan tingkat kesukaran butir soal mengikuti kriteria yang dikemukakan oleh Hambleton \& Swminathan (1985) yaitu rentang \pm 2 (antara -2 hingga +2$)$, dengan interpretasi nilai -2 menunjukkan butir soal sangat mudah dan +2 menunjukkan butir soal sangat sulit. Hasil analisis tingkat kesukaran butir soal dengan menggunakan Partial Credit Model (PCM) melalui program quest versi 2.0 disajikan pada tabel 5.

\begin{tabular}{|clcccc|}
\hline No & \multicolumn{2}{c}{ Aspek Berpikir Ilmiah } & $\begin{array}{c}\text { Nomor } \\
\text { butir soal }\end{array}$ & $\begin{array}{c}\text { Nilai Tingkat } \\
\text { Kesukaran } \\
\text { (Difficulty) }\end{array}$ & \multicolumn{2}{c|}{ Delta } \\
\cline { 5 - 7 } & Mengamati/Memahami & 1 & 0.29 & 0.45 & 0.13 \\
\hline 2. & Menanya/ merumuskan pertanyaan & 2 & $-0,19$ & -0.57 & 0.19 \\
\hline 3. & $\begin{array}{l}\text { Mencari sumber data/mengumpulkan } \\
\text { informasi }\end{array}$ & 3 & -0.145 & -0.48 & 0.19 \\
\hline 4. & Melakukan penalaran & 4 & 0.285 & 0.4 & 0.17 \\
\hline 5. & Mengaplikasikan/mengkomunikasikan & 5 & 0.34 & 0.57 & 0.11 \\
\hline
\end{tabular}

Tabel 4. Tingkat kesukaran butir soal

Berdasarkan tabel 5 diatas maka dapat disimpulkan bahwa semua butir soal berada diantara nilai -2 hingga +2 sehingga berdasarkan nilai diatas, tidak ada butir soal yang dibuang.

\section{Analisis hasil uji kemampuan berpikir ilmiah}

Hasil uji kemampuan berpikir ilmiah berdasarkan persentase setiap kategori jawaban dapat dilihat pada tabel 5. 
DIAKRONIKA 21 (1) 2021

ISSN: 1411-1764 (Print) | 2620-9446 (Online)

\begin{tabular}{|c|c|c|c|c|c|}
\hline \multirow{2}{*}{ No } & \multirow{2}{*}{ Aspek Berpikir Ilmiah } & \multirow{2}{*}{$\begin{array}{c}\text { Nomor } \\
\text { butir } \\
\text { soal }\end{array}$} & \multicolumn{3}{|c|}{$\begin{array}{l}\text { Persentase jawaban siswa (\%) } \\
\text { berdasarkan kategori }\end{array}$} \\
\hline & & & 1 & 2 & 3 \\
\hline 1. & Mengamati/Memahami & 1 & 36.7 & 21.7 & 33.3 \\
\hline 2. & Menanya/ merumuskan pertanyaan & 2 & 20 & 33.3 & 41.7 \\
\hline 3. & $\begin{array}{l}\text { Mencari sumber data/mengumpulkan } \\
\text { informasi }\end{array}$ & 3 & 23.3 & 35.0 & 36.7 \\
\hline 4. & Melakukan penalaran & 4 & 16.7 & 40 & 28.3 \\
\hline 5. & Mengaplikasikan/mengkomunikasikan & 5 & 23.3 & 18.3 & 38.3 \\
\hline & Rata-rata & & & & 35,66 \\
\hline
\end{tabular}

Tabel 5. Persentase Distribusi jawaban siswa berdasarkan kategori jawaban

Tabel 5 menunjukkan persentase distribusi jawaban siswa berdasarkan jawaban dengan kategori 3. Kriteria pencapaian hasil belajar peserta didik mengadaptasi Adip, dkk (2009) sebagai berikut:

\begin{tabular}{c|c}
\hline Tingkat Pencapaian & Predikat Keberhasilan \\
\hline $86-100 \%$ & Sangat Tinggi \\
\hline $71-85 \%$ & Tinggi \\
\hline $56-70 \%$ & Sedang \\
\hline $41-55 \%$ & Rendah \\
\hline$<40 \%$ & Sangat Rendah \\
\hline
\end{tabular}

Tabel 6. Kriteria predikat keberhasilan belajar siswa

Berdasarkan kriteria pencapaian hasil belajar peserta didik, maka dapat disimpulkan bahwa pendekatan saintifik melalui indikator $5 \mathrm{M}$, hanya mampu meningkatkan potensi berpikir ilmiah siswa sebesar 35,66\% dengan kategori sangat rendah.

\section{Diskusi}

Temuan penelitian menunjukkan bahwa pendekatan saintifik $5 \mathrm{M}$ yang menjadi indikator umum berpikir ilmiah, belum mampu menjadi indikator berpikir ilmiah yang 
Ofianto, Tri Zahra Ningsih

Analisis Pendekatan Saintifik sebagai Indikator Berpikir Ilmiah dalam

Pembelajaran Sejarah

baik dalam pembelajaran sejarah. Hal ini ditegaskan oleh hasil penelitian yang menunjukkan bahwa pendekatan saintifik hanya mampu meningkatkan potensi berpikir ilmiah siswa sebesar $35,66 \%$ dengan kategori sangat rendah. Hasil penelitian ini mengindikasikan bahwa berpikir ilmiah dalam pembelajaran sejarah lebih dari sekedar meniru tahap-tahap metode ilmiah yang dibawa ke dalam kelas, akan tetapi siswa benarbenar diajak untuk melakukan prosedur ilmiah dalam melakukan rekonstruksi narasi sejarah melalui penyelidikan peristiwa masa lalu, mengumpulkan bukti, mengeksplorasi sumber sejarah, menganalisis setiap sumber sejarah, hingga menarik kesimpulan terhadap suatu peristiwa sejarah (Peter Seixas, 2017; Sundayana, 2016; van Boxtel et al., 2021).

Sehingga, untuk melakukan setiap tahapan ilmiah tersebut dibutuhkan indikator berpikir ilmiah khusus yang dapat digunakan untuk meningkatkan keterampilan berpikir ilmiah dalam mata pelajaran sejarah. Temuan ini memperkuat hasil penelitian Haydn (2011) bahwa studi sejarah di sekolah belum menyediakan kerangka kerja yang koheren yang dapat digunakan untuk memahami masa lalu dengan baik, sehingga diperlukan pengembangan kerangka kerja yang dapat digunakan siswa yang memungkinkan mereka untuk mengartikulasikan elemen masa lalu dengan saat ini dengan cara yang tepat. Penelitian Harris \& Reynolds (2014) juga menunjukkan bahwa kurangnya konsensus tujuan pendidikan sejarah dalam meningkatkan keterampilan berpikir ilmiah menyebabkan belum adanya indikator yang tepat untuk meningkatkan kemampuan berpikir siswa dalam pembelajaran sejarah.

Berdasarkan temuan penelitian, maka penulis merekomendasikan historical literacy skill, historical thinking skill, historical consciousness, dan historical reasoning skill untuk dijadikan sebagai indikator berpikir ilmiah dalam pembelajaran sejarah. Keempat keterampilan memiliki keterkaitan dan saling bersinergi dalam membangun keterampilan berpikir ilmiah dengan cara-cara sebagaimana seorang ilmuan bekerja yaitu melalui tahapan tahapan ilmiah (Efstathiou et al., 2018; Innes, 2020; Peter Seixas, 2017; van Boxtel et al., 2021). Pertama, melalui historical literacy skill paling tidak ada tiga potensi yang harus dimiliki siswa, diantaranya (1) pemahaman tentang sejarah sebagai cara melihat dunia. Ini melibatkan pemahaman akan disiplin sejarah dan ide-ide kunci yang memungkinkan pengetahuan tentang masa lalu. Siswa dibantu untuk memperoleh perangkat konseptual yang memungkinkan mereka untuk memahami berbagai jenis klaim yang dibuat oleh sejarah, dan bagaimana kita mengetahui, menjelaskan dan memberikan penjelasan tentang masa lalu; (2) keinginan untuk menghasilkan argumen yang valid dan memberi rasa hormat terhadap orang-orang di masa lalu. Siswa tidak cukup hanya mengetahui bahwa sejarah dapat menjawab pertanyaan tentang masa lalu, namun untuk melek secara historis siswa harus memiliki disposisi tertentu; dan (3) bagaimana mata pelajaran sejarah diajarkan sebagai pemahaman mendalam yang 
mengubah informasi faktual menjadi pengetahuan yang dapat digunakan (Donovan et al., 1999). Keterampilan historical literacy melibatkan pengetahuan substantif yang koheren (kadang-kadang disebut konten historis) yang diselenggarakan dalam bentuk masa lalu yang dapat digunakan untuk masa kini dan masa depan.

Kedua, Historical Thinking Skill, melalui keterampilan ini siswa dimungkinkan untuk dapat (1) membedakan masa lalu, masa sekarang, dan masa yang akan datang; (2) membangun pertanyaan; (3) mencari dan mengevaluasi bukti- bukti; (4) membandingkan dan menganalisis kisah-kisah sejarah, ilustrasi-ilustrasi, dan catatan-catatan dari masa lalu; (5) menginterpretasikan catatan- catatan sejarah, dan (6) merekonstruksi sejarah menurut versi siswa masing-masing. Hal ini memberikan makna bahwa belajar sejarah tidak hanya mengetahui tentang fakta-fakta, tanggal, nama, tempat dan peristiwa yang disajikan, namun lebih dari itu siswa dituntut untuk memahami makna dibalik unsurunsur tersebut sehingga siswa mampu mengkonstruksi sejarah menurut versinya masingmasing. Historical Thinking Skill melibatkan urutan peristiwa, analisis waktu dan tempat kejadian peristiwa dalam konteks untuk membantu dalam pembangunan makna dan pemahaman.

Ketiga, Historical Consciousness skill merupakan prasyarat untuk menengahi antara nilai dan tindakan. Rüsen (2004) menyebutkan bahwa Historical Consciousness sebagai orientasi yang digunakan dalam memecahkan situasi saat ini. Melalui Historical Consciousness siswa tidak hanya melihat sejarah sebagai kompleksitas pengetahuan, persepsi dan gagasan tentang masa lalu, tetapi sebagai suatu kesadaran akan konteks spesifik tertentu (kontinuitas, diskontinuitas, dan perubahan) antara masa lalu (dalam ingatan kolektif), masa kini dan masa depan serta sebagai suatu kesadaran yang berkontribusi untuk membentuk sikap terhadap masa kini dan masa depan. Lebih lanjut Körber \& Meyer-Hamme (2015) menyebutkan terdapat empat kompetensi yang dapat dikuasai siswa melalui keterampilan Historical Consciousness yaitu (1) kompetensi merancang pertanyaan sejarah, termasuk pertanyaan tentang fenomena sejarah dalam kehidupan sehari-hari; (2) kompetensi metodologi untuk membangun kembali penjelasan sejarah dari sumber informasi dan secara analitis merancang dan mengevaluasi pernyataan teoritis; (3) kompetensi untuk menghubungkan penilaian dan kesimpulan orang lain tentang masa lalu dengan kehidupan sendiri dan masyarakat; dan (4) kompetensi memahami konsep substantif dan memahami dan menggunakan konsep sejarah.

Keempat, Historical Reasoning skill menuntut siswa untuk mampu menggunakan pengetahuan dalam rangka menafsirkan berbagai fenomena masa lalu dan masa kini. Van Drie \& Van Boxtel (2008) menyebutkan ada enam komponen yang harus dimiliki siswa melalui Historical Reasoning Skill yaitu (1) siswa mampu bertanya, mengenali dan 
Ofianto, Tri Zahra Ningsih

Analisis Pendekatan Saintifik sebagai Indikator Berpikir Ilmiah dalam

Pembelajaran Sejarah

memahami pertanyaan sejarah sebagai salah satu kompetensi yang mendasari pemikiran sejarah, (2) siswa mampu menggunakan sumber sejarah dalam aktivitas penelitian maupun pembelajaran sejarah karena informasi dari sumber penting untuk mendukung kebenaran tentang masa lalu, (3) siswa memiliki kemampuan mengkontekstualisasi, sebab dalam memahami dan menafsirkan peristiwa sejarah membutuhkan pengetahuan tentang konteks sejarah yang dibentuk berdasarkan karakteristik waktu dan tempat berlangsungnya peristiwa, (4) siswa mampu membangun argumentasi, hal ini penting dimiliki siswa karena catatan sejarah didasarkan pada berbagai macam sumber yang sering memuat informasi parsial dan kontradiktif dan karena interpretasi sejarah tidak pasti maka pernyataan dan klaim tentang masa lalu harus didukung oleh argumentasi rasional, (5) siswa mampu menggunakan konsep yang substantive yang mengacu pada fenomena sejarah, struktur, orang dan periode, dan (6) siswa mampu menggunakan meta konsep, yaitu metode yang digunakan untuk menyelidiki dan menggambarkan proses dan periodisasi sejarah. Meta konsep berguna dalam memandu siswa menanyakan pertanyaan tentang masa lalu serta deskripsi, perbandingan, dan penjelasan fenomena sejarah serta penggunaan sumber dalam sebuah argumentasi.

Keempat keterampilan sebagaimana yang disebut sebelumya juga sejalan dengan tujuan pendidikan sejarah di sekolah sebagaimana dikemukakan oleh Metzger \& Harris (2018) yaitu (1) mengembangkan keterampilan berpikir sejarah siswa dan kapasitas memahami diri mereka sendiri sebagai makhluk sejarah yang dibentuk oleh masa lalu dan akan berkontribusi untuk masa kini dan masa yang akan depan; (2) mengembangkan empati siswa yang memungkinkan untuk memahami konteks yang berbeda di masa lalu tetapi juga peduli bagaimana masa lalu mempengaruhi orang saat ini; (3) mempersiapkan siswa untuk berpikir, membaca, dan menulis dengan cara yang berhubungan dengan ahli sejarah; (4) mempersiapkan siswa untuk terlibat dalam interpretasi sejarah berbasis bukti tentang sebab-akibat dan signifikansi; dan (5) melatih siswa untuk mengkritik penggunaan sejarah di media, museum, dan situs budaya. Berdasarkan diskusi di atas, maka disimpulkan bahwa keterampilan historical literacy, historical thinking, historical consciousness, dan historical reasoning dapat menjadi indikator berpikir ilmiah dalam pembelajaran sejarah.

\section{Kesimpulan}

Hasil penelitian yang dilakukan menunjukkan bahwa pendekatan saintifik hanya mampu meningkatkan potensi berpikir ilmiah siswa sebesar 35,66\% dengan kategori sangat rendah. Hal ini menjadi bukti bahwa generalisasi indikator 
berpikir ilmiah melalui pendekatan saintifik belum dapat digunakan sebagai indikator peningkatan keterampilan berpikir ilmiah dalam pembelajaran sejarah. Berdasarkan hal tersebut, penulis merekomendasikan historical literacy skill, historical thinking skill, historical historical consciousness, dan historical reasoning skill untuk dijadikan sebagai indikator berpikir ilmiah dalam pembelajaran sejarah dengan pertimbangan bahwa keempat keterampilan ini memiliki kerangka kerja yang sama yaitu menggunakan metode-metode ilmiah dalam penyelidikan peristiwa sejarah. Adapun implikasi dari penelitian ini adalah supaya guru mata pelajaran sejarah di SMA dapat menerapkan keempat keterampilan ini sebagai indikator untuk menganalisis keterampilan berpikir ilmiah siswa dalam pembelajaran sejarah. Selain itu, penelitian ini hanya terbatas pada memberikan rekomendasi untuk indikator berpikir ilmiah yang terbatas historical literacy skill, historical thinking skill, historical historical consciousness, dan historical reasoning skill, sehingga disarankan untuk melakukan penelitian yang lebih mendalam lagi tentang efektifitas penerapan keempat indikator berpikir ilmiah ini dalam pembelajaran sejarah.

\section{Daftar Pustaka}

Abdullah. (2014). wawancara tanggal 10 Juni 2014.

Adams, R. J., \& Khoo, S. T. (1996). Quest: Interactive item analysis system. Version 2.1. Andrich, D. (1978). A rating formulation for ordered response categories. Psychometrika, 43(4), 561-573.

Bacon, F. (1854). Novum organum (B. Monatgue, Trans.). Philadelphia, $P$.

Donovan, M. S., Bransford, J. D., \& Pellegrino, J. W. (1999). Eds. How people learn: bridging research and practice. National Academy Press. [cited].

Duquette, C. (2015). Relating historical consciousness to historical thinking through assessment. New Directions in Assessing Historical Thinking, 51-63.

Efstathiou, I., Kyza, E. A., \& Georgiou, Y. (2018). An inquiry-based augmented reality mobile learning approach to fostering primary school students' historical reasoning in non-formal settings. Interactive Learning Environments, 26(1), 22-41.

Galilei, G. (1914). Dialogues concerning two new sciences. Dover.

Harris, R., \& Reynolds, R. (2014). The history curriculum and its personal connection to students from minority ethnic backgrounds. Journal of Curriculum Studies, 46(4), 464486.

Haydn, T. (2011). History teaching and ICT. Debates in History Teaching, 236-248.

Innes, M. (2020). Dynamic Literacies and Democracy: A Framework for Historical Literacy. In The Palgrave Handbook of History and Social Studies Education (pp. 597-620). Springer.

Klahr, D. (2000). Exploring science: The cognition and development of discovery processes. MIT press. 
Ofianto, Tri Zahra Ningsih

Analisis Pendekatan Saintifik sebagai Indikator Berpikir Ilmiah dalam

Pembelajaran Sejarah

Körber, A., \& Meyer-Hamme, J. (2015). Historical thinking, competencies, and their measurement. New Directions in Assessing Historical Thinking, 89-101.

Lee, P. (2007). From national canon to historical literacy. In Beyond the Canon (pp. 48-62). Springer.

Martínez-Hita, M., Gómez-Carrasco, C. J., \& Miralles-Martínez, P. (2021). The effects of a gamified project based on historical thinking on the academic performance of primary school children. Humanities and Social Sciences Communications, 8(1), 1-10.

Metzger, S. A., \& Harris, L. M. (2018). The Wiley international handbook of history teaching and learning. Wiley Online Library.

Napitupulu, S., Manalu, D., \& Siahaan, S. (2019). Scientific approach-based English learning strategy (SABELS). The New Educational Review, 56(2), 41-52.

Pitafi, A. I., \& Farooq, M. (2012). Measurement of scientific attitude of secondary school students in Pakistan. Academic Research International, 2(2), 379.

Rüsen, J. (2004). Historical consciousness: Narrative structure, moral function and ontogenetic development. Teoksessa Seixas, Peter (toim.), Theorizing Historical Consciousness. Toronto: University of Toronto Press, 63, 85.

Seixas, P. (2013). Lingking historical thinking concepts, content and competencies. A Report on the National Meeting of the Historical Thinking Project.

Seixas, Peter. (2006). Benchmarks of historical thinking: A framework for assessment in Canada. The Center for the Study of Historical Consciousness. Recuperado El, 16, 1-12.

Seixas, Peter. (2017). A model of historical thinking. Educational Philosophy and Theory, 49(6), 593-605.

Seixas, Peter, \& Peck, C. (2004). Teaching historical thinking. Pacific Educational Press.

Sundayana, R. (2016). Statistika Penelitian Pendidikan. Alfabeta.

Tweney, R. D., Doherty, M. E., \& Mynatt, C. R. (1981). On scientific thinking.

Van Boxtel, C., \& van Drie, J. (2018). Historical reasoning: Conceptualizations and educational applications. The Wiley International Handbook of History Teaching and Learning, 149-176.

van Boxtel, C., Voet, M., \& Stoel, G. (2021). Inquiry learning in history. In International Handbook of Inquiry and Learning (pp. 296-310). Routledge.

Van Drie, J., \& Van Boxtel, C. (2008). Historical reasoning: Towards a framework for analyzing students' reasoning about the past. Educational Psychology Review, 20(2), 87110.

Wright, B. D., \& Masters, G. N. (1982). Rating scale analysis. MESA press. 